\title{
Advanced respiratory monitoring in COVID- 19 patients: use less PEEP!
}

\author{
Lisanne Roesthuis", Maarten van den Berg and Hans van der Hoeven
}

Keywords: Coronavirus disease 2019, Acute respiratory distress syndrome, Positive end-expiratory pressure, Lung compliance, Dead space ventilation, Hyperinflation

To the Editor,

In the majority of coronavirus disease 2019 (COVID19) patients, respiratory mechanics is different from the "normal" acute respiratory distress syndrome (ARDS) patient. Plateau pressures and driving pressures are often low and respiratory system compliance relatively normal compared to the ARDS patient [1]. Many physicians use high positive end-expiratory pressure (PEEP) for patients with COVID-19 although the potential for recruitment is often low $[1,2]$. We fear that the high compliance of the respiratory system in combination with high PEEP will lead to hyperinflation, high dead space, and potentially right ventricular failure.

We have used the following strategy for COVID-19 patients $(N=70)$ : after intubation, immediately prone positioning for at least 3 days, using the lowest possible PEEP to obtain adequate oxygenation with $\mathrm{FiO}_{2}$ of $50 \%$. We assessed the effects of different PEEP levels on respiratory mechanics and ventilation-perfusion mismatching.

\section{Methods}

Respiratory mechanics was assessed in COVID-19 patients admitted to the Radboud University Nijmegen Medical Center as part of standard patient care. Brief occlusions were performed to assess end-inspiratory and end-expiratory airway and transpulmonary pressures (absolute and elastance ratio method) and to calculate respiratory and lung compliances as previously described

\footnotetext{
* Correspondence: Lisanne.Roesthuis@Radboudumc.nl Department of Intensive Care Medicine, Radboud University Medical Center, Geert Grooteplein-Zuid 10, 6525 GA Nijmegen, The Netherlands
}

$[3,4]$. Dead space ventilation was assessed using two methods:

1) The Bohr equation using partial pressure of carbon dioxide in alveolar air $\left(\mathrm{PACO}_{2}\right)$ and mixed expired air $\left(\mathrm{PeCO}_{2}\right)$ : $\left(\mathrm{PACO}_{2}-\mathrm{PeCO}_{2}\right) / \mathrm{PACO}_{2}$. See our previous work for detailed description [5].

2) The Enghoff modification of Bohr's equation using partial pressure of carbon dioxide in arterial blood $\left(\mathrm{PaCO}_{2}\right):\left(\mathrm{PaCO}_{2}-\mathrm{PeCO}_{2}\right) / \mathrm{PaCO}_{2}$. Therefore, shunt and diffusion limitations are taken into the equation.

\section{Results}

Advanced respiratory mechanics was assessed in 14 patients $(8$ males and 6 females, age (mean \pm SEM) $67 \pm 2$ years, body mass index $\left.28.0 \pm 0.9 \mathrm{~kg} / \mathrm{m}^{2}\right)$ between the 19th of March and 2nd of April (Table 1). Compliance of the respiratory system was low $\left(42 \pm 3 \mathrm{~mL} / \mathrm{cmH}_{2} \mathrm{O}\right)$ due to a lower than normal lung compliance $(61 \pm 5 \mathrm{~mL} /$ $\mathrm{cmH}_{2} \mathrm{O}$ ). However, compared to ARDS patients, lung compliance was relatively high, resulting in low endinspiratory transpulmonary pressures $\left(12 \pm 1 \mathrm{cmH}_{2} \mathrm{O}\right)$. Chest wall compliance was slightly lower than normal due to prone positioning in most patients. COVID-19 patients had high dead space ventilation and gas exchange impairment (Bohr $52 \pm 3 \%$; Enghoff modification $67 \pm 2 \%)$.

Reducing PEEP resulted in an increase in lung compliance and decrease in dead space ventilation, except for patient 1 (Fig. 1). 
Table 1 Respiratory mechanics

\begin{tabular}{|c|c|c|c|c|c|c|c|c|c|c|c|c|c|}
\hline Patient no. & MV days & $\mathrm{FiO}_{2}$ & $\begin{array}{l}\mathrm{PaO}_{2} / \mathrm{FiO}_{2} \\
(\mathrm{mmHg})\end{array}$ & $\begin{array}{l}\mathrm{PaCO}_{2} \\
(\mathrm{mmHg})\end{array}$ & $\begin{array}{l}P_{\text {plateau }} \\
\left(\mathrm{cmH}_{2} \mathrm{O}\right)\end{array}$ & $\begin{array}{l}P_{\text {drive }} \\
\left(\mathrm{cmH}_{2} \mathrm{O}\right)\end{array}$ & $P_{\mathrm{L}, \mathrm{e}-\mathrm{i}}$ & $\begin{array}{l}P_{\mathrm{L}, \text { drive }} \\
\left(\mathrm{cmH}_{2} \mathrm{O}\right)\end{array}$ & $\begin{array}{l}\mathrm{C}_{\mathrm{rs}} \\
\left(\mathrm{mL} / \mathrm{cmH}_{\mathbf{2}} \mathrm{O}\right)\end{array}$ & $\begin{array}{l}\mathrm{C}_{\mathrm{L}} \\
\left(\mathrm{mL} / \mathrm{cmH}_{\mathbf{2}} \mathrm{O}\right)\end{array}$ & $\begin{array}{l}\text { Enghoff } \\
(\%)\end{array}$ & $\begin{array}{l}\text { Bohr } \\
(\%)\end{array}$ & Position \\
\hline 1 & 7 & 0.50 & 156 & 87 & 22 & 8 & 9 & 5 & 55 & 82 & - & - & $P$ \\
\hline \multirow[t]{2}{*}{2} & 2 & 0.45 & 208 & 56 & 24 & 7 & 17 & 18 & 54 & 79 & - & - & $S$ \\
\hline & 3 & 0.55 & 124 & 57 & 26 & 8 & - & - & 48 & - & 66 & 47 & $S$ \\
\hline 3 & 0 & 0.50 & 228 & 44 & 23 & 9 & 17 & 16 & 47 & 62 & 66 & 56 & $S$ \\
\hline 4 & 1 & 0.60 & 123 & 44 & - & - & - & - & - & - & 71 & 58 & $P$ \\
\hline \multirow[t]{2}{*}{5} & 0 & 0.40 & 214 & 48 & 23 & 13 & 9 & 9 & 40 & 54 & 55 & 42 & $P$ \\
\hline & 1 & 0.40 & 278 & 44 & 18 & 10 & 7 & 8 & 50 & 64 & 48 & 38 & $P$ \\
\hline 6 & 1 & 0.45 & 143 & 49 & - & - & - & - & - & - & 63 & 40 & P \\
\hline 7 & 1 & 0.55 & 183 & 55 & 23 & 14 & 11 & 10 & 36 & 50 & 60 & 42 & $P$ \\
\hline 8 & 1 & 0.40 & 176 & 52 & 16 & 8 & 7 & 5 & 56 & 95 & 64 & 51 & $P$ \\
\hline \multirow[t]{2}{*}{9} & 0 & 0.95 & 98 & 61 & 29 & 12 & 14 & 9 & 38 & 50 & - & - & $P$ \\
\hline & 5 & 0.60 & 143 & 89 & 27 & 12 & 14 & 9 & 35 & 45 & 72 & 60 & P \\
\hline 10 & 1 & 0.80 & 125 & 53 & 21 & 10 & 11 & 7 & 36 & 49 & 66 & 52 & $P$ \\
\hline 11 & 2 & 0.55 & 147 & 49 & 21 & 12 & 11 & 10 & 40 & 51 & 69 & 47 & P \\
\hline \multirow[t]{2}{*}{12} & 2 & 0.75 & 113 & 59 & 25 & 11 & 11 & 8 & 26 & 37 & 69 & 57 & P \\
\hline & 3 & 0.65 & 111 & 47 & 26 & 12 & 11 & 8 & 27 & 40 & 71 & 60 & $P$ \\
\hline 13 & 1 & 0.50 & 192 & 67 & 24 & 12 & 10 & 7 & 47 & 76 & 82 & 74 & $P$ \\
\hline 14 & 6 & 0.70 & 150 & 62 & 28 & 15 & 15 & 11 & 31 & 43 & 65 & 52 & P \\
\hline
\end{tabular}

$C_{r s}$ compliance of respiratory system, $C_{L}$ lung compliance, $M V$ days days of mechanical ventilation at the time of measurement, $P_{L, e-i}$ end-inspiratory transpulmonary pressure, $P_{L, \text { drive }}$ transpulmonary driving pressure, $P$ prone position, $S$ supine position 


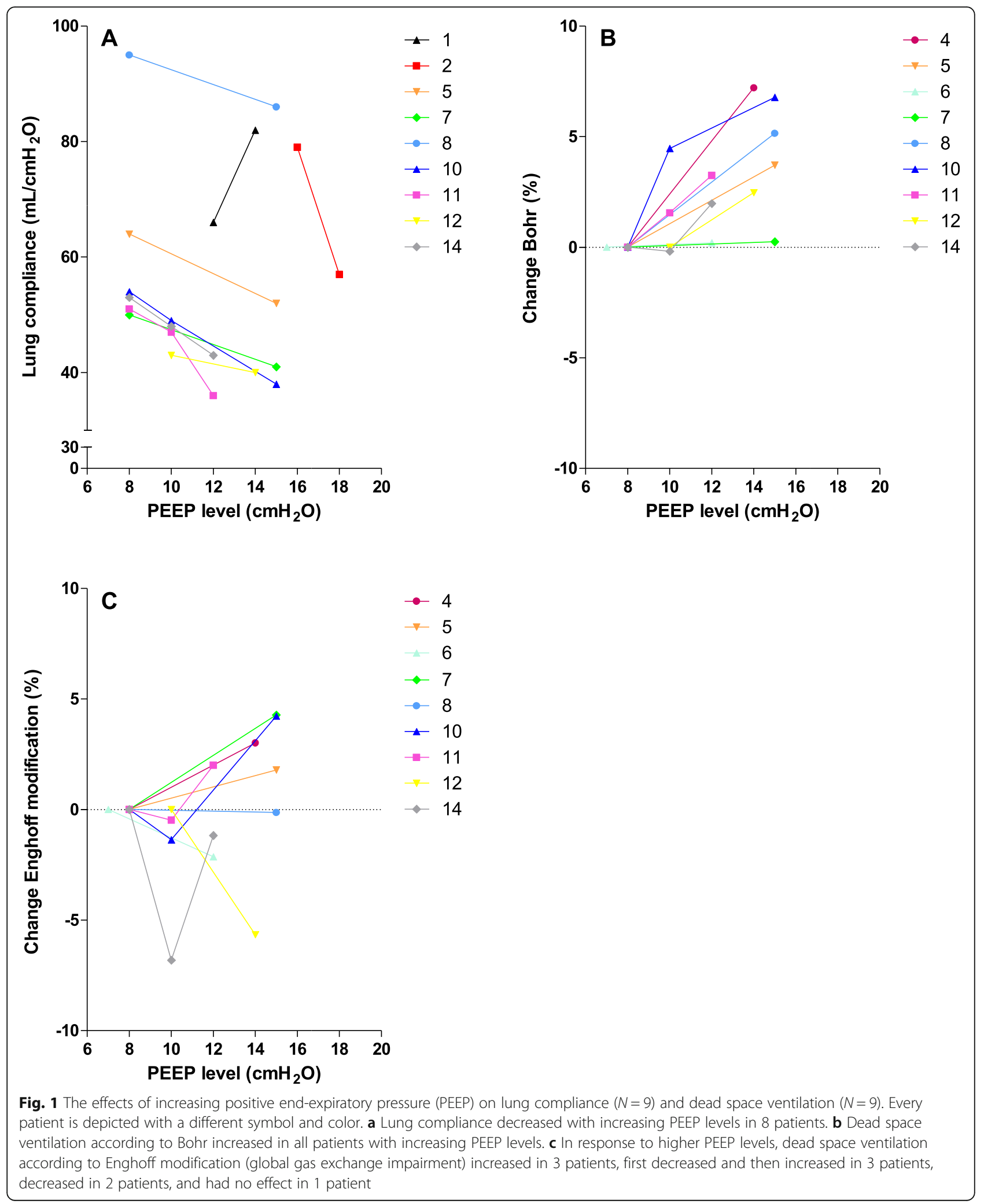




\section{Discussion}

We demonstrate that mechanically ventilated patients with COVID-19 have a relatively high lung compliance, high dead space ventilation, and gas exchange impairment. In almost all patients, lung compliance decreased and dead space ventilation increased with increasing PEEP levels.

The decrease in lung compliance and increase in dead space ventilation in response to higher PEEP levels indicate that COVID-19 lesions were not recruited and that higher PEEP levels cause hyperinflation of the more compliant parts of the lung [1]. These results are in accordance with recent findings in COVID-19 patients [2].

When lung compliance increases in response to higher PEEP levels (patient 1), recruitment is likely and PEEP should be set accordingly $[1,2]$.

All patients responded extremely well to prone positioning, although the exact mechanism is unclear. Redistribution of blood flow seems to be an important mechanism.

In conclusion, we show that higher PEEP levels decrease lung compliance and in most cases increase dead space ventilation, indicating that high PEEP levels probably cause hyperinflation in patients with COVID-19. We suggest using prone position for an extended period of time (e.g., 3-5 days) and apply lower PEEP levels as much as possible.

\section{Abbreviations}

ARDS: Acute respiratory distress syndrome; COVID-19: Coronary virus disease 2019; $\mathrm{PACO}_{2}$ : Partial pressure of carbon dioxide in alveolar air; $\mathrm{PaCO}_{2}$ : Partial pressure of carbon dioxide in arterial blood; $\mathrm{PeCO}_{2}$ : Partial pressure of carbon dioxide in mixed expired air; PEEP: Positive end-expiratory pressure;

SEM: Standard error of the mean

\section{Acknowledgements}

Not applicable.

\section{Authors' contributions}

Data acquisition: LR. Data analysis: LR. Data interpretation: all authors. Manuscript drafting and revising: all authors. The authors read and approved the final manuscript.

\section{Funding}

There was no financial funding.

\section{Availability of data and materials}

The datasets used and analyzed during the current study are available from the corresponding author on reasonable request.

\section{Ethics approval and consent to participate}

Due to standard patient care and the urgent need to gain knowledge about this new lung disease, informed consent was deemed unnecessary, but also not feasible in most cases.

\section{Consent for publication}

Not applicable.

\section{Competing interests}

The authors declare that they have no competing interests.
Received: 28 April 2020 Accepted: 7 May 2020

Published online: 15 May 2020

\section{References}

1. Gattinoni L, Chiumello D, Caironi P, Busana M, Romitti F, Brazzi L, et al. COVID-19 pneumonia: different respiratory treatments for different phenotypes? Intensive Care Med. 2020. Epub ahead of print.

2. Pan C, Chen L, Lu C, Zhang W, Xia JA, Sklar MC, et al. Lung Recruitability in SARS-CoV-2 associated acute respiratory distress syndrome: a single-center, observational study. Am J Respir Crit Care Med. 2020. Epub ahead of print.

3. Akoumianaki E, Maggiore SM, Valenza F, Bellani G, Jubran A, Loring SH, et al The application of esophageal pressure measurement in patients with respiratory failure. Am J Respir Crit Care Med. 2014;189(5):520-31.

4. Yoshida T, Amato MBP, Grieco DL, Chen L, Lima CAS, Roldan R, et al. Esophageal manometry and regional transpulmonary pressure in lung injury. Am J Respir Crit Care Med. 2018;197(8):1018-26.

5. Doorduin J, Nollet JL, Vugts MP, Roesthuis LH, Akankan F, van der Hoeven $J G$, et al. Assessment of dead-space ventilation in patients with acute respiratory distress syndrome: a prospective observational study. Crit Care. 2016;20(1):121.

\section{Publisher's Note}

Springer Nature remains neutral with regard to jurisdictional claims in published maps and institutional affiliations.
Ready to submit your research? Choose BMC and benefit from:

- fast, convenient online submission

- thorough peer review by experienced researchers in your field

- rapid publication on acceptance

- support for research data, including large and complex data types

- gold Open Access which fosters wider collaboration and increased citations

- maximum visibility for your research: over $100 \mathrm{M}$ website views per year

At $\mathrm{BMC}$, research is always in progress.

Learn more biomedcentral.com/submissions 